\title{
ENSURING INFLAMMATION DOES MORE GOOD THAN HARM
}

PROFESSOR JÁNOS G FILEP IS AN IMMUNOLOGIST BASED AT THE UNIVERSITY OF MONTREAL IN CANADA. HIS WORK IS CONCERNED WITH UNDERSTANDING THE MECHANISMS OF INFLAMMATION THAT OCCUR IN CARDIOVASCULAR DISEASE. THE FINDINGS COULD LEAD TO IMPROVED PATIENT OUTCOMES

\section{TALK LIKE AN IMMUNOLOGIST}

\section{RECEPTOR}

A protein or glycoprotein that receives signals by binding to signalling molecules. These are often referred to as first messengers or ligands.

\section{LIGAND}

A small molecule that transmits signals in between or within cells. By binding to receptors, ligands can exert their effects.

\section{LIPID}

A molecule that yields high energy and has a chemical composition of carbon, hydrogen and oxygen. They are an important component of living cells.

\section{PATHOGEN}

A bacterium, virus or other microorganism that can cause disease.
The human body is a wonderful thing. It is an extraordinarily complex machine that is constantly working to ensure we can go about our daily lives unimpeded. Indeed, so effective is this mechanism, that it is easy to take for granted how much effort our bodies put in to protecting us against infections, viruses, diseases and a whole host of other potential invaders.

One of the ways in which the body protects itself against infection or injury is by triggering an acute inflammatory response. However, while the mechanisms of the inflammatory response are specifically designed to protect us against invading pathogens, sometimes they can inflict damage on our own tissues and actually do more harm than good. Certainly, ongoing (chronic) inflammation underlies most diseases.

Why might this be so? And can anything be done to prevent this from happening? Researchers from around the world are asking these very questions. Their aim is to resolve many of the issues associated with the inflammatory response, including Professor János G Filep, based in the Department of Pathology and Cell Biology at the University of Montreal Canada. He leads a team which is focused on inflammation that occurs in cardiovascular disease. The findings could have significant positive impacts on patient outcomes.

\section{WHAT IS THE INFLAMMATORY} RESPONSE?

When the human body is affected by infection or injury, it triggers an acute inflammatory response with the aim of protecting itself. It is the immune system that is responsible for orchestrating the response - one that is similar irrespective of what triggered it. The signs of inflammation include swelling, redness of the inflamed area, warmth, pain and impaired function of the organ(s) affected.

When the inflammatory response works in the way we want it to, the invading pathogens are eliminated and the infected or injured tissues are repaired. They then return to their normal function and we can live as we did prior to the attack - this is known as the resolution of inflammation. However, it is not always this straightforward. If the resolution is delayed, ongoing inflammation might actually damage the organ(s) it is trying to protect. 

